\title{
RISK FACTORS FOR CARDIOVASCULAR DISEASES IN PHYSICIANS
}

\author{
Marie Nakládalováa, Eliška Sovováb, Kateřina Ivanovác, Markéta Kaletováb, \\ Jan Lukl ${ }^{b}$, Jarmila Fialováa
}

\author{
a Department of Occupational Medicine, Teaching Hospital, Palacký University, I.P.Pavlova 6, 775 20 Olomouc, Czech \\ Republic \\ ${ }^{b} I^{\text {st }}$ Department of Internal Medicine, Teaching Hospital, Olomouc, Palacký University, I. P. Pavlova 6, 775 20 Olomouc, \\ Czech Republic \\ c Institute of Social Medicine and Health Policy, Faculty of Medicine, Palacký University, Hněvotínská 3, 775 15 Olomouc, \\ Czech Republic \\ e-mail: marie.nakladalova@fnol.cz
}

Received: October 3, 2005; Accepted (with revisions): November 2, 2005

Keywords: Risk factors/Cardiovascular disease/Smoking/Prevention

The aim of the study was to determine the prevalence of risk factors for cardiovascular diseases among physicians at a teaching hospital. In total, 203 men and 167 women were included in the study. The participants filled in a questionnaire; their height, weight, blood pressure, serum cholesterol and glucose levels were added. $19.2 \%$ males and $13.8 \%$ females were smokers, hypertension was diagnosed in $10 \%$ of males and in $6.6 \%$ of females, $52.2 \%$ males and $17.4 \%$ females were overweight, $37 \%$ males and $43.1 \%$ females had hypercholesterolemia. The above findings suggest that Czech physicians have more favourable values of all the studied cardiovascular diseases risk factors than the general Czech population. However, Czech physicians smoke more than those in other countries and their level of cardiovascular diseases risk factors is unsatisfactory and calls for further intensive prevention. Preliminary outcomes of the study repeated after two years show no positive trends as well as physicians' low willingness to actively participate in lowering cardiovascular diseases risk factors.

\section{INTRODUCTION}

In the Czech Republic, mortality due to cardiovascular disease (CVD) has been slowly decreasing since the mid1980s, yet it is still significantly higher than in the states of Western Europe. Standardized mortality rates for diseases of the circulatory system in the year 2003 were 568 for males and 384 for females per 100,000 of the European population (standard), accounting $52.2 \%$ of all deaths ${ }^{1}$. Since health care workers are one decisive factor in any health strategies employed they should also set an example by taking care of their own health. Thus the aim of our pilot study was primary prevention of cardiovascular diseases in physicians working in the Teaching Hospital in Olomouc. The text lists the prevalence of CVD risk factors, comparison with results of studies conducted in other countries and with the prevalence in the general population of the Czech Republic. Preliminary outcomes of the study repetition after two years show no positive trends as well as physicians' low willingness to actively participate in lowering CVD risk factors.

\section{MATERIAL AND METHODS}

The physicians at their preventive occupational medical examination filled in a questionnaire, subject to agreement, concerning smoking, physical activity, prevalence of diabetes mellitus, hypertension or CVD. Collected data also included height, weight, blood pressure and serum total cholesterol levels. All physicians received a personal letter stating the obtained biochemical values as well as a proposal to target intervention of potential risk factors. Brochures containing advice on CVD prevention were also enclosed. The physicians were offered visits to advice centres for overweight and smoking and the possibility to have their exercise plans designed.

Over the period of 2002-2004, 370 physicians were examined, with the average age of 39.5 years (SD 10.7), including 203 males aged 38.9 (SD 10.27) on average and 167 females aged 40.3 (SD 11.18) on average. Those smoking regularly (daily) at present were considered smokers. Blood pressure of $140 / 90 \mathrm{~mm} \mathrm{Hg}$ or use of antihypertensives were considered hypertension. All cholesterol levels above the laboratory standard rate $(5.0 \mathrm{mmol} / 1)$ were considered increased. Obesity was defined as a BMI of at least $30 \mathrm{~kg} / \mathrm{m}^{2}$ whereas BMI values ranging from 25.0 to $29.9 \mathrm{~kg} / \mathrm{m}^{2}$ were indicative of overweight. Daily physical activity lasting at least $20 \mathrm{~min}$ or $1 \mathrm{~h}$ of physical activity twice a week were considered regular exercise. 


\section{RESULTS AND DISCUSSION}

Prevalence of CVD risk factors is shown in Table 1.

Where applicable, the results were statistically processed by the chi-square method using contingency tables with the Yates correction and a 0.05 significance level. These were subsequently compared with data obtained by similar methods in groups of physicians from Sao Paulo, Brazil (SP), Hungary (H), India (I), Wales (W) and West Virginia , USA (WV)(ref. ${ }^{2-6}$ ) and data from extensive studies of representative samples of the Czech population ${ }^{7-8}$.

Smoking was reported in $16.7 \%$ of Czech physicians included in our study, as compared to $17.4 \%$ in SP (not significant - NS) and $26 \%$ in H (NS)(ref., ${ }^{2,3}$ ). The proportion of smokers in male physicians was $19.2 \%$ while the rates were $8 \%$ in the $1994 \mathrm{WV}$ study and only $2.3 \%$ in I $(\mathrm{p}<0.001)\left(\right.$ ref. $\left.^{6,4}\right)$. Female smokers constituted $13.8 \%$ of our sample, only $1.9 \%$ in the WV study and there were no female smokers in the I study $(p<0.001)\left(\right.$ ref. $\left.^{6,4}\right)$. The report of a questionnaire survey in the representative sample of the general Czech population revealed smoking in $30.3 \%$ of males and $18.9 \%$ of females, i.e. rates higher than those found in physicians $(p<0.001)\left(\right.$ ref. $\left.^{7}\right)$. On the other hand, the prevalence of smoking male physicians in the Czech Republic is nearly twice as high as in WV and the difference is even more significant in females. The low percentage of smokers in the USA can be explained by the fact that the anti-smoking campaign began a long time ago and no smoking has been widely supported by the American society.

Hypertension was diagnosed in $10 \%$ of Czech male physicians and in $6.6 \%$ of females. The prevalence of hypertension in Czech medical professionals (8.6\%) was similar to that in their counterparts in SP $(8.4 \%)$ but lower than that in the I study where the values for males and females were $33.5 \%(\mathrm{p}<0.001)$ and $20 \%$ (NS), respectively $^{2,4}$. In the 2000-2001 study following the MONICA project $(n=804)$, hypertension in the general Czech population was detected in $45.6 \%$ of males and
$33 \%$ of females. When compared to these outcomes the situation in the studied group of physicians is statistically significantly better $(\mathrm{p}<0.001)\left(\right.$ ref. $\left.^{8}\right)$.

In most cases, the prevalence of total cholesterol level above standard does not differ from the reviewed studies in other countries. An increased cholesterol level was found in $37.4 \%$ of Czech male physicians, as compared with $40 \%$ in W (NS) and $44.8 \%$ in I (NS)(ref. ${ }^{5,4}$ ). The only exception is SP where the $14 \%$ proportion of health care professionals demonstrate higher total cholesterol level $(\mathrm{p}<0.001)^{2}$. Unlike the general Czech population, the average concentration of total cholesterol in both male and female health care professionals is lower (general population - males: $5.88 \pm 1.08$, male physicians: $4.99 \pm 1.03$, $(p<0.001)$; general population - females: $5.82 \pm 1.13 \mathrm{mmol} / 1$, female physicians: $5.03 \pm 0.97 \mathrm{mmol} / 1$, $(\mathrm{p}<0.001)\left(\right.$ ref. $\left.^{8}\right)$.

In our study group, $52.2 \%$ of males and $17.4 \%$ of females were found to be overweight, as opposed to $39 \%$ $(\mathrm{p}<0.001)$ and $29 \%$ (NS), respectively, in $\mathrm{W}^{5}$. The prevalence of obesity in Czech physicians is $10.8 \%$ in males and $5.9 \%$ in females which is less than in WV (males: $20 \%$, females: $13 \%)^{6}$. Obesity is also statistically significantly less $(p<0.001)$ prevalent in physicians enrolled in our study than in the general Czech population (males: $20.9 \%$, females: $18.3 \%)\left(\right.$ ref. $\left.^{7}\right)$.

Regular exercise was reported by $66.5 \%$ of males and $61.1 \%$ of females in our study. Such high numbers were quite surprising. The data may be biased as the participants may have tried to make better impression and also our criteria were not as strict as those in the WV study (30 minutes three times per week) where $48 \%$ of male and $47 \%$ of female physicians reported regular exercise. The W study stated that $56 \%$ of males and $32 \%$ of females exercised on a regular basis ${ }^{5}$. Low physical activity was declared by $7.9 \%$ of males and $7.2 \%$ of females in our sample $(8.9 \%$ of males and $10.3 \%$ of females in the general Czech population) ${ }^{7}$.

Table 1. Prevalence of CVD risk factors in Czech physicians

\begin{tabular}{|c|c|c|c|c|c|c|}
\hline \multirow{2}{*}{ Risk factor } & \multicolumn{2}{|c|}{$\begin{array}{c}\text { total } \\
\mathrm{n}=370\end{array}$} & \multicolumn{2}{|c|}{$\begin{array}{c}\text { males } \\
\mathrm{n}=203\end{array}$} & \multicolumn{2}{|c|}{$\begin{array}{l}\text { females } \\
n=167\end{array}$} \\
\hline & $\mathrm{N}$ & $\%$ & $\mathrm{n}$ & $\%$ & $\mathrm{~N}$ & $\%$ \\
\hline Smoking & 62 & 16.7 & 39 & 19.2 & 23 & 13.8 \\
\hline Regular exercise & 237 & 64.0 & 135 & 66.5 & 102 & 61.1 \\
\hline Hypertension & 32 & 8.6 & 22 & 10.1 & 11 & 6.6 \\
\hline Diabetes mellitus & 3 & 0.8 & 1 & 0.5 & 2 & 1.2 \\
\hline Overweight & 135 & 36.0 & 106 & 52.2 & 29 & 17.4 \\
\hline Obesity & 32 & 8,6 & 22 & 10,8 & 10 & 5,9 \\
\hline Hypercholesterolemia & 148 & 40.0 & 76 & 37.4 & 72 & 43.1 \\
\hline
\end{tabular}

BMI: body mass index 
The above mentioned comparison suggests that the Czech physicians have more favourable values of all the studied CVD risk factors than the general Czech population. However, the Czech physicians smoke more than those in other countries and their level of CVD risk factors is unsatisfactory and calls for further intensive prevention.

The physicians never took the opportunity to visit the advice centres. Although all physicians with an overall high risk of CVD (risk rating of CVD emanated from common European recommendations for prevention of these maladies ${ }^{9}$ ) were invited for another examination at the department of preventive cardiology, only 13 out of 39 did come. This is in contrast with a group of bank employees assessed in the same way at our departments as all those invited for another examination did come.

Also an important finding is that the preliminary results of the same examination of 80 physicians carried out two years later show no statistically significant improvement in any of the studied parameters. The positive effect is very weak as only three doctors gave up smoking and seven started their hypertension treatment.

What causes the physicians' resistance to active intervention of their risk factors? Is not enough stress put on prevention during their education? Were they not interested in further preventive activities because - as they face human diseases and physical distress on an everyday basis - they neglect taking care of their own health unless they have some difficulties? The authors suggest that primary prevention of CVD becomes a common part of occupational medical preventive examinations of both physicians and other health care professionals. Moreover, other options should be considered that would lead to improved primary prevention of CVD, including those aimed at changing attitudes.

\section{ACKNOWLEDGEMENT}

This work was partly funded by the project of Ministry of Health of the Czech Republic called Project of Health Promotion 2003, no. 8096, Organisation of Primary Prevention of Cardiovascular Diseases

\section{REFERENCES}

1. Ústav zdravotnických informací a statistiky: Zemřelí 2003.(Institute of Medical Information and Statistics: Departed 2003.) Praha: ÚZIS ČR, 2004.

2. Dioquardi GS, Pimenta J, Knoplich J, Ghotayeb N, Ramos LR, Giannini SD. (1994) Risk factors for cardiovascular diseases in physicians. Preliminary data from the VIDAM project of the Paulista Medical Association. Arq Bras Cardiol 62, 383-8

3. Márk L, Nagy E, Kondacs A, Deli L. (1998) The change of attitude of Hungarian physicians towards the importance of risk factors of coronary heart disease over the period 1985-1996. Public Health 112, 197-201.

4. Gupta A, Gupta R, Lal B, Singh AK, Kothari K. (2001) Prevalence of coronary risk factors among Indian physicians. J Assoc Physicians India 49, 1148-52

5. Nutbeam D, Catford J. (1990) Modifiable risks for cardiovascular disease among general practitioners in Wales. Public Health 104, 353-61

6. Gault R, Yeater RA, Ullrich IH. (1994) West Virginia physicians: cardiovascular risk factors, lifestyles and prescribing habits. W V Med J 90, 364-6

7. Ústav zdravotnických informací a statistiky ČR (Institute of Medical Information and Statistics). Světové šetření o zdraví v České republice. Praha: ÚZIS ČR, 2004.

8. Cífková, R., Škodová, Z. (2004) Dlouhodobé trendy hlavních rizikových faktorů kardiovaskulárních onemocnění v české populaci. Čas Lék čes 143, 219-26

9. Wood D, Faegeman O, Pyörälä K, De Backer G, Graham I, Mancia G on behalf of the Task Force. (1998) Prevention of coronary heart disease in clinical practice. Recommendation of the Second Joint task Force of European and Societies on coronary prevention. Eur Heart J 19, 1434-503 